\title{
Geotechnical Investigation of a Collapsed building site in Port Harcourt, Rivers State Nigeria
}

\author{
${ }^{1}$ Youdeowei, P.O \\ ${ }^{1}$ Institute of Geosciences and Space Technology (IGST), \\ Rivers State University, Port Harcourt, \\ Rivers State, Nigeria.
}

\author{
${ }^{2}$ Rowland-Lato, E.O. \\ ${ }^{2}$ Works and Services Department, \\ University of Port Harcourt, Choba, \\ Rivers State, Nigeria.
}

\begin{abstract}
The recent collapse of a 7-storey building still under construction in Port Harcourt which caused the loss of several lives led the State government to set up a judicial panel of enquiry to find out the immediate and remote causes. A geotechnical team was commissioned to investigate the subsoil conditions at the site. This study and its findings are informed by these activities. The sub-soil investigation was conducted by drilling five (5) well spaced and site representative boreholes with a light cable Percussion rig to depths of $35 \mathrm{~m}$ each. Soil samples were logged and SPT soundings were conducted. Undisturbed and disturbed soil samples were also recovered for Laboratory analysis in accordance with BS 1377. The soil stratigraphy revealed brownish silty clay overburden of $6 \mathrm{~m}$ depth with moderate plasticity underlain by medium grained, loose to moderately dense sand ( $N$ values of 3-33) to the maximum drilled depth. Natural moisture content of the Clay soils ranged from 16.20 to $21.30 \%$ while the plasticity index varied from 15.66 to $21.33 \%$. The shear strength parameters of these $c-\phi$ soils gave average values of $46 \mathrm{kPa}$ and 4.5 degrees as undrained cohesion and undrained angle of internal friction, respectively. The net foundation pressure or allowable bearing capacity for a shallow foundation at the site was computed as $135 \mathrm{KPa}$ at a settlement of $33 \mathrm{~mm}$ for a foundation breadth of 1 to $2.5 \mathrm{~m}$ to a depth of $3 \mathrm{~m}$. For the deep foundation, the safe pile load or allowable pile (axial) capacity at a depth of $35 \mathrm{~m}$ were calculated for the five (5) boreholes. The result gave average values of $406 \mathrm{KN}$ and $508 \mathrm{KN}$ for tubular driven steel cased piles of 14 " $(356 \mathrm{~mm})$ diameter and 16" $(406 \mathrm{~mm})$ diameter, respectively. It was strongly recommended that all piles be terminated at the medium dense sand layer at a depth not less than $30 \mathrm{~m}$. Furthermore, the pile foundation design should be validated with a pile load test to confirm the design load adopted and pile settlement. It was noted that inadequate depth of pile embedment and the absence of a pile load test to determine the safe load capacity of the piles must have been major causes of the subsoil and structural foundation failure.
\end{abstract}

Key words: Collapsed building, geotechnical investigation, bearing capacity, pile foundation, pile load test, Port Harcourt.

\section{INTRODUCTION}

The frequency of collapsed buildings in recent years resulting in much loss of lives, properties and superstructures in Port Harcourt has been a great cause for concern. Reasons adduced are mostly ascribed to poor quality building materials. While this may be true, less attention is paid on the sub-surface soil condition that bears the foundation. The need to understand and determine the load carrying capacity of these soils and recommend the appropriate foundation type for the structures as the basic geotechnical and civil engineering requirement before construction is of utmost importance [1]; [2]. This study sadly is coming only after yet another failed building episode with all its attendant grave consequences.

The collapse of a 7-storey building still under construction on the $23^{\text {rd }}$ of November, 2018, at the GRA phase 2, Port Harcourt which caused the loss of several lives led the State government to set up a judicial panel of enquiry to find out the immediate and remote causes. A geotechnical team was commissioned to investigate the sub-soil conditions at the site. This study and its findings are informed by these activities. The purpose of this study is to present the details of the geotechnical investigation activities at the collapsed building site. The investigation is aimed at providing geotechnical information for the possible causes of the collapsed building.

\section{STUDY LOCATION AND GEOLOGY}

The project site is in Port Harcourt, Rivers State, within the Niger Delta region. It lies within a sub-horizontal geomorphologic terrain with a measure of undulations arising from uneven surface area erosion. Ground elevation range between 10-12 meters above mean sea level. The local geology is of the coastal plain sand, which is Miocene in age and form parts of the uppermost strata of the outcropping Benin Formation [3]; [4]. These consist of extensive thickness of brownish, coarse to medium sand with subordinate clay and silt. There are drainage problems with seasonal and temporary flooding due to heavy rainfall (mean annual rainfall exceeds $2000 \mathrm{~mm}$.) and rise in groundwater table. The site is about $120 \mathrm{~m}$ from the nearby Ntawoba creek. The area is associated with luxuriant freshwater vegetation typical of a tropical rainforest.

\section{METHODOLOGY}

\section{A. Field Exploration}

Subsurface conditions at the site were studied by boring Five (5) holes (BH) to depths of $35 \mathrm{~m}$ each at the collapsed building site using a light cable Percussion 
rig of the Pilcon Wayfarer type with the aid of augers, clay cutter and shell. Percussion drilling method permits more accurate sampling of the cuttings as brought up with the bailer and more accurate determination of groundwater levels. Soil samples were retrieved at depths of $1.0 \mathrm{~m}$ intervals and at points where a conspicuous change in soil lithology was observed, for visual examination, laboratory testings and classification. Undisturbed cohesive soil samples were recovered with the aid of U-4 tubes and as boring advanced, Standard Penetration Test (SPT) was conducted to determine the penetration resistance values of cohesionless soils at specific depths within the boreholes. It is a useful tool to determine in situ density and relative density. The boreholes layout is presented in Fig.1, while the variation of SPT values with depth for a representative borehole at the site is seen in Fig.2. Figure 3 shows the drilling activities by the field crew at the site.

The water level at the site was generally at about $3.6 \mathrm{~m}$ below the ground level at the time of investigation in December, 2018. This will be subject to seasonal fluctuations. The site is also about $120 \mathrm{~m}$ from the Ntawoba creek. The implication is that groundwater recharge may be enhanced with water infiltrating the confining permeable layers from the creek.

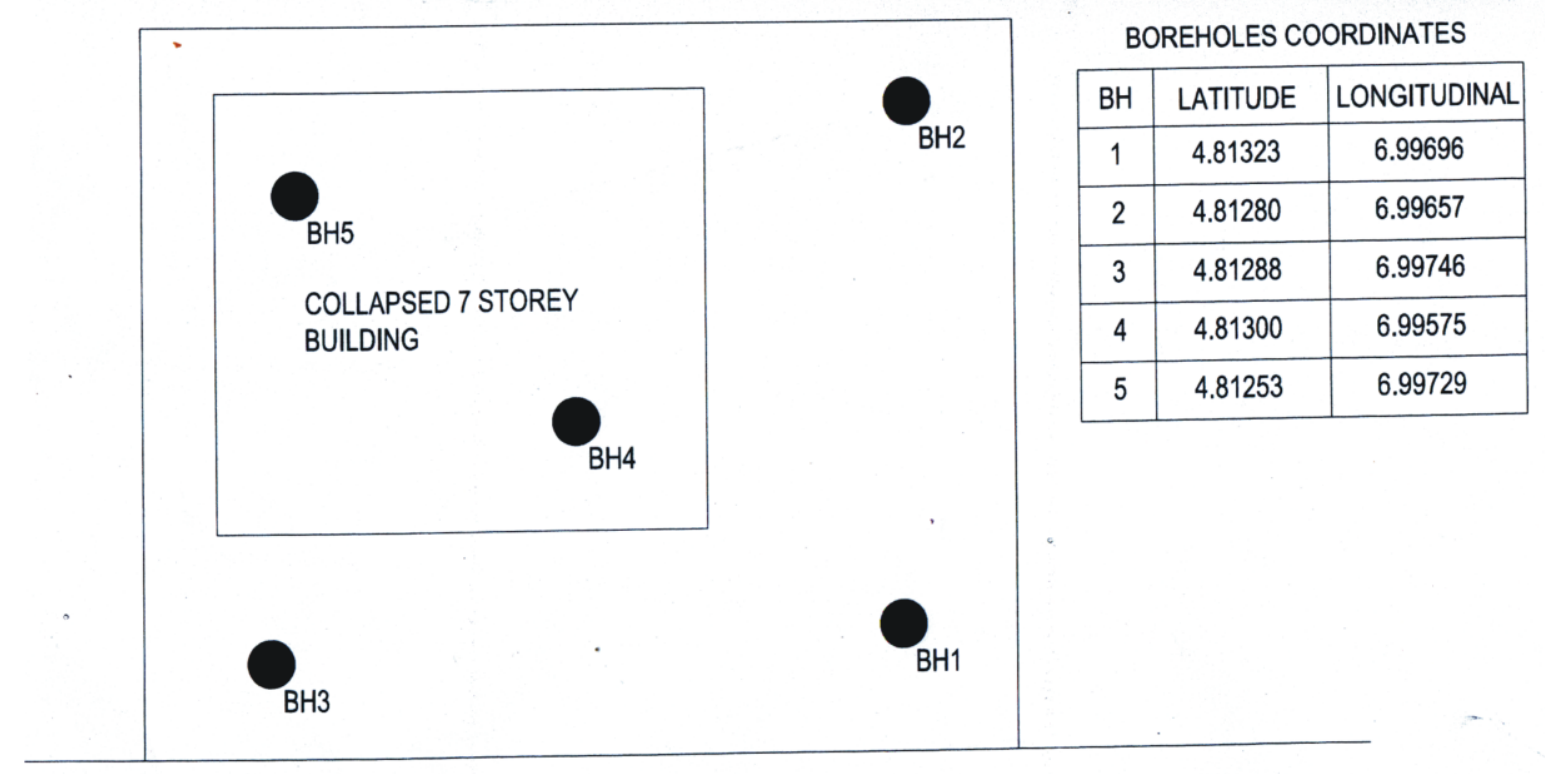

WOJI ROAD, GRA PHASE II PORT HARCOURT

Fig. 1: Layout Of Boreholes At The Site 


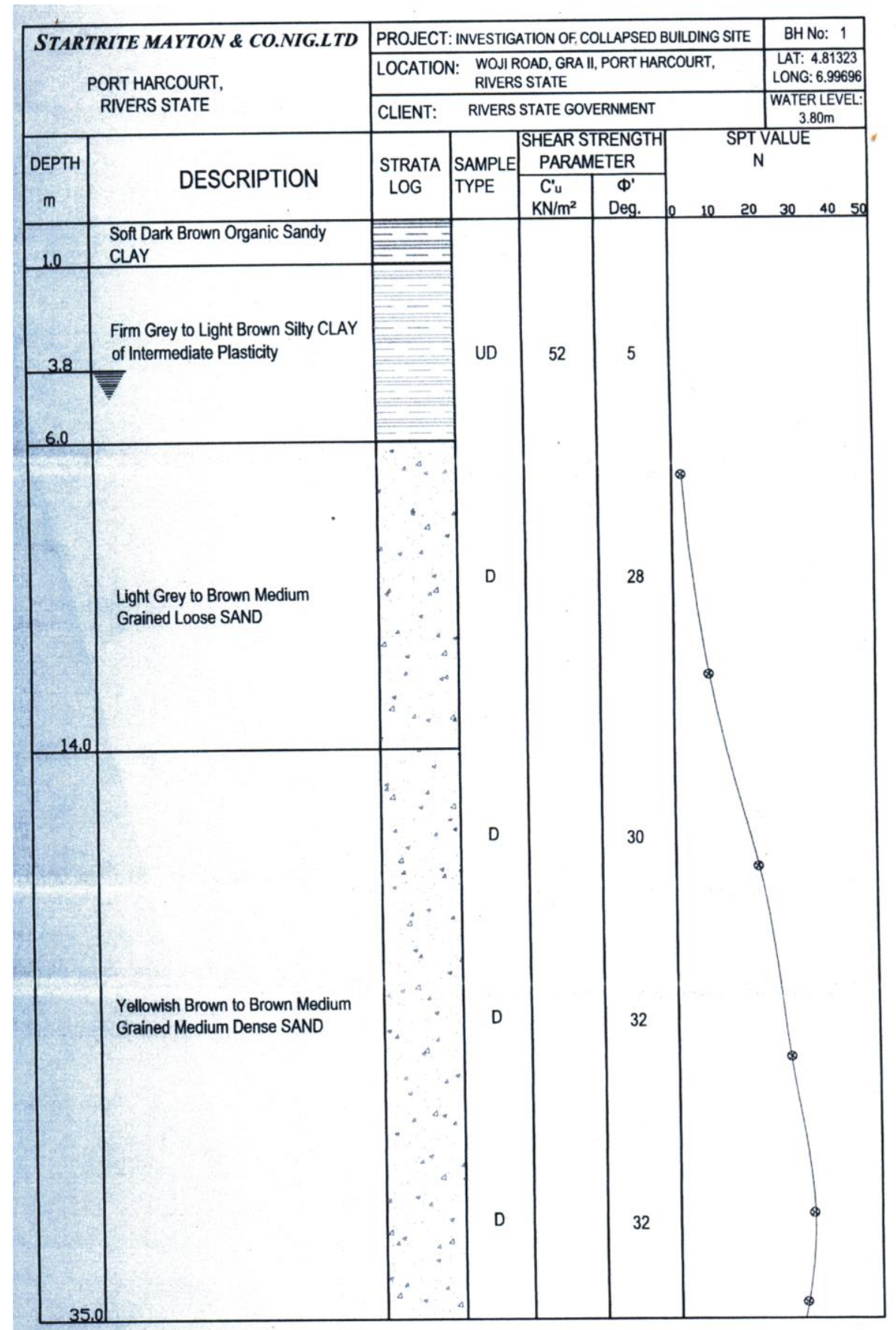

Fig. 2: Boreholes Log with SPT Values (BH1) 


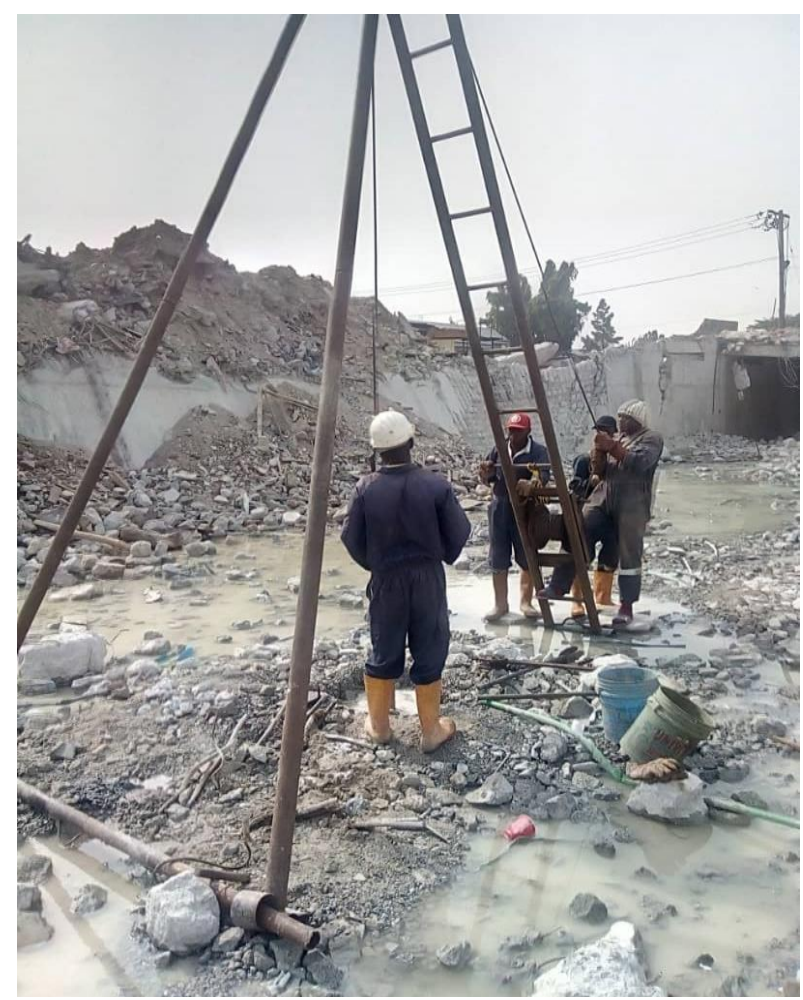

Fig. 3: Field crew drilling at the collapsed building site.

\section{B. Laboratory Tests}

The conventional soil mechanics tests relevant to the intended project were carried out. The following tests were conducted in accordance with BS 1377[5] - Method of test for soils for Civil Engineering purposes which is equivalent to ASTM (1979)[6]. The tests were to enable the evaluation of the gradation, consistency, strength and settlement characteristics of the sub-soils at the project site that will influence the choice of foundations and design considerations.

\section{-Classification Tests}

This was obtained based on the following laboratory test results:

(i) Atterberg Limits Tests (consisting of liquid and plastic limits). (ii) Particle size distribution.

The cohesive soil samples of $\mathrm{BH} 1$ to $\mathrm{BH} 5$, which were obtained from the borings, were analyzed by wet sieving to obtain the coarse grained fractions of the soil sample, while the cohesionless soil fractions were subjected to dry sieving. The Atterberg limits of the plastic soils were analyzed using the Casagrande liquid limit apparatus.

Soil classification was based on the British soil classification system (BSCS) and the unified soil classification system (USCS) and is shown in Table 1, while the table and graphs of the particle size distribution is presented in Figure 4. Soils that have the same classification tend to have the same engineering behavior [7]. 


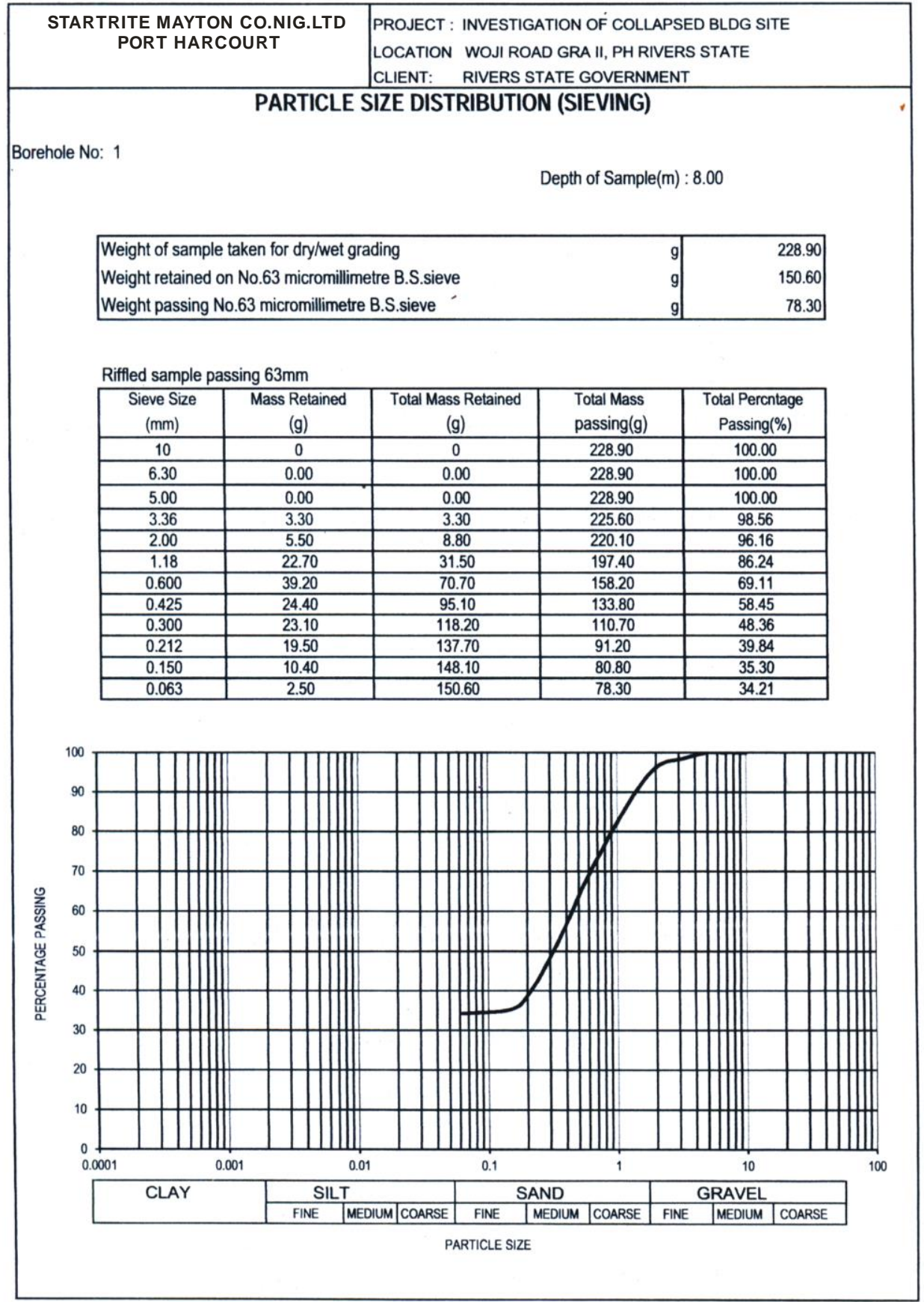

Fig. 4: Particle Size Distribution Curve of Bh1 at $8 \mathrm{~m}$ Sample Depth

-Triaxial Test

Unconsolidated undrained triaxial compression tests were carried out on cohesive soil samples of BH1 to BH5. The shear strength parameters of undrained cohesion $\left(\mathrm{c}_{\mathrm{u}}\right)$ and undrained angle of internal friction $\left(\phi_{\mathrm{u}}\right)$ of the $c-\phi$ soils are obtained from unconsolidated undrained triaxial compression tests. Three soil samples were respectively subjected to cell pressures of
$100 \mathrm{kN} / \mathrm{m}^{2}, 200 \mathrm{kN} / \mathrm{m}^{2}$ and $300 \mathrm{kN} / \mathrm{m}^{2}$ and the soil samples were sheared to failure by incrementally loaded deviator stress. The deviator stresses at failure of each cell pressure were analyzed and the shear strength parameters of the soil evaluated. A plot of the Mohr circle for the respective major principal stresses at failure and the applied cell pressures of a representative cohesive soil sample are shown in Fig.5. 


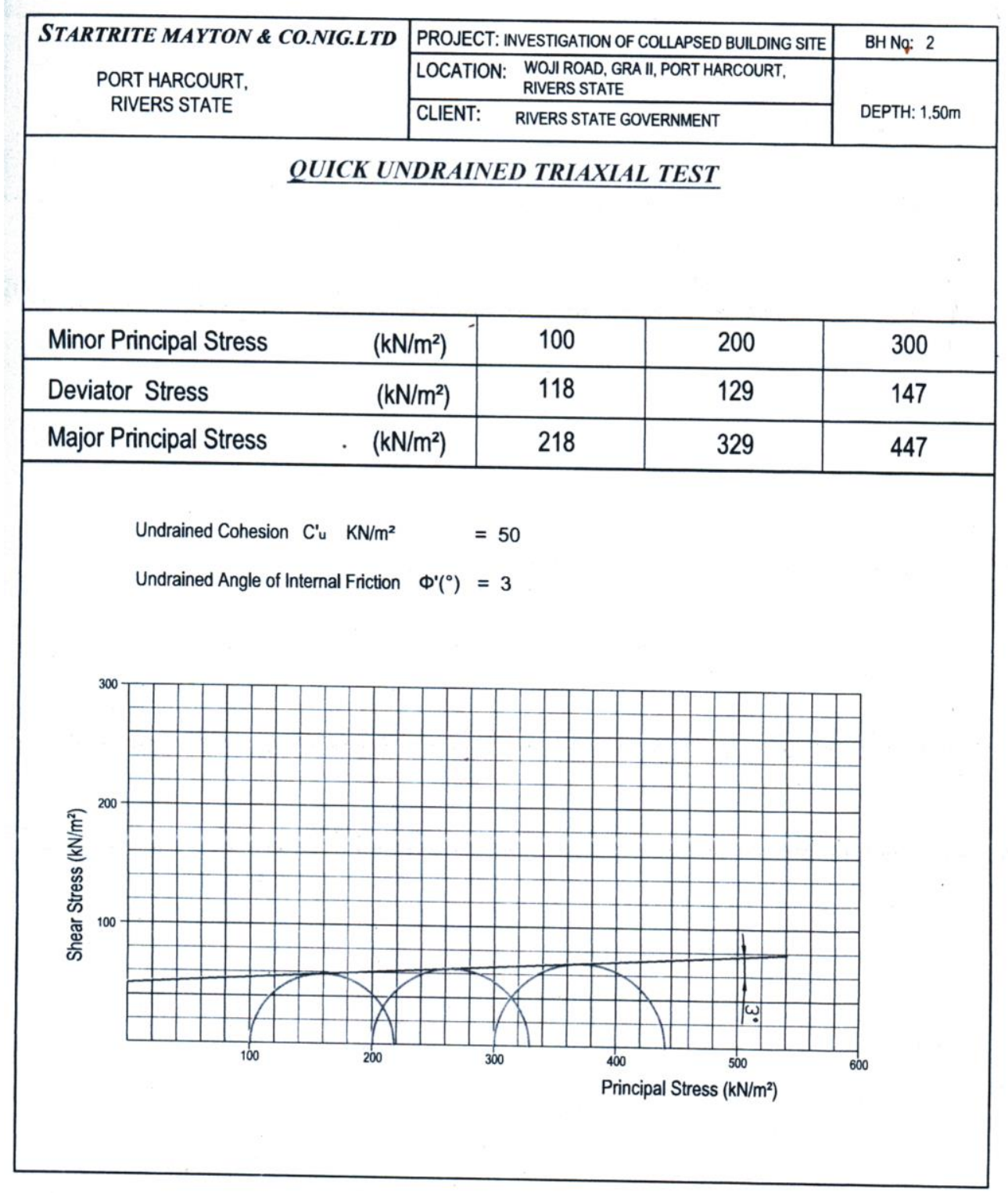

Fig. 5: Result of Shear Strength Test of Silty Clay Soil in Borehole 2

\section{-Consolidation Test}

One-dimensional oedometer consolidation tests were carried out on the cohesive soil samples of the boreholes. This test is aimed at determining the relevant settlement properties of the soil which are used in evaluating foundation settlement. The values of coefficient of volume compressibility $\left(\mathrm{M}_{\mathrm{v}}\right)$, initial void ratio $\left(\mathrm{e}_{\mathrm{o}}\right)$, specific gravity $\left(\mathrm{G}_{\mathrm{s}}\right)$ and natural moisture content $(\mathrm{w} \%)$ of a representative soil sample is also shown in Fig. 6. 


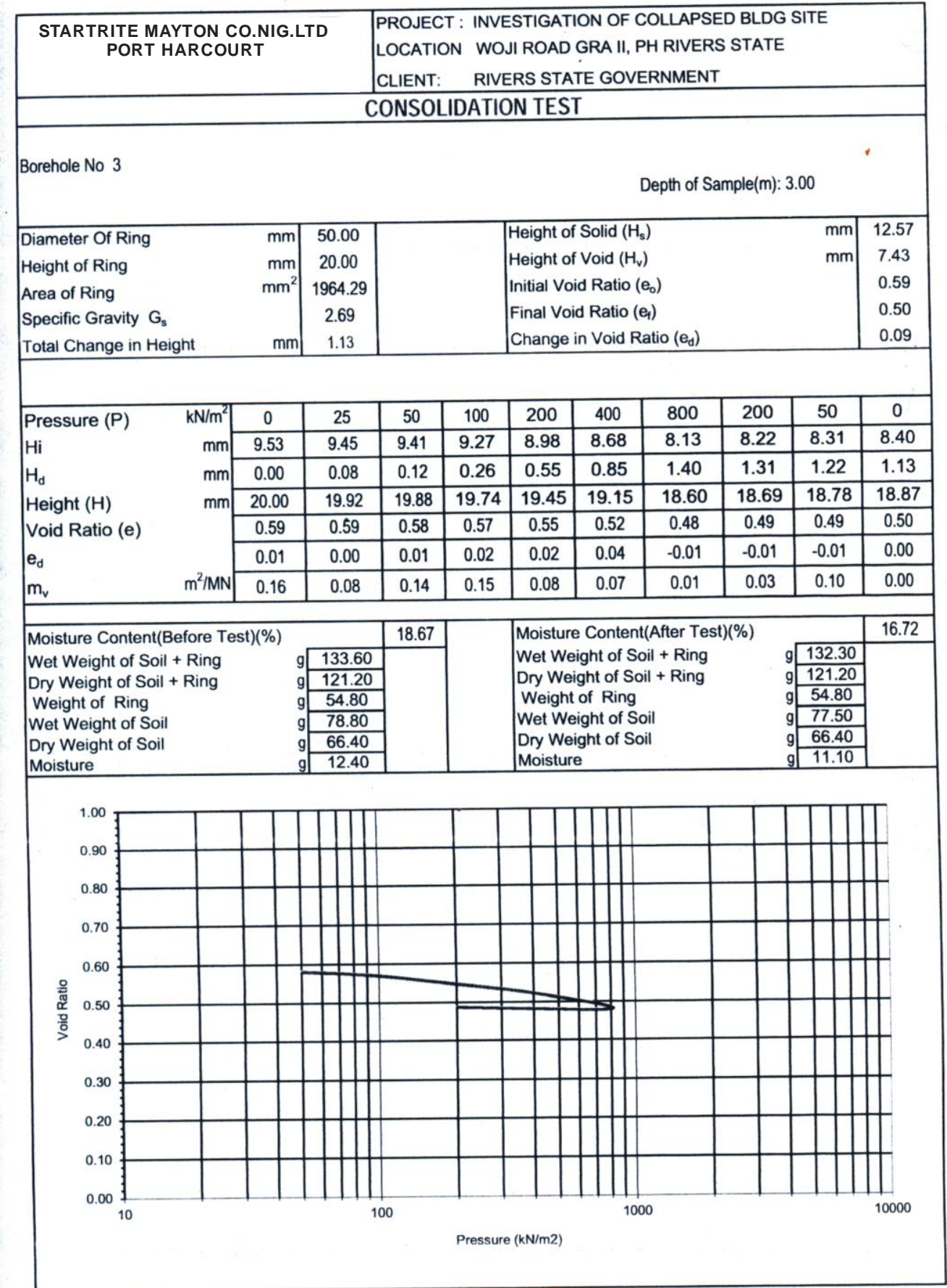

\section{Fig. 6: Consolidation Test Result of Silty Clay Soil at 3m Depth in BH3}

\section{DISCUSSION OF RESULTS}

Soil Stratigraphy and Classification

Classification tests revealed the plastic soils as generally consisting of grey to brownish, CLAY of intermediate plasticity and medium grained, medium dense, SAND up to the depth of investigation from the ground surface. A summary of the Atterberg limits and plasticity index of the soils are shown in Table 1. 
Table 1: Atterberg limits.

\begin{tabular}{|c|c|c|c|c|c|c|}
\hline $\begin{array}{r}\text { Borehole } \\
\text { No. }\end{array}$ & $\begin{array}{l}\text { Sample Depth } \\
\text { (m) }\end{array}$ & $\begin{array}{l}\text { Liquid } \\
\text { Limit } \\
\quad(\%)\end{array}$ & $\begin{array}{c}\text { Plastic } \\
\text { Limit } \\
(\%)\end{array}$ & $\begin{array}{l}\text { Plasticity } \\
\quad \text { Index }(\%)\end{array}$ & BSCS & USCS \\
\hline 1 & $\begin{array}{l}0.75-6.00 \\
6.00-35.00\end{array}$ & $\begin{array}{c}37.26 \\
\mathrm{~Np}\end{array}$ & $\begin{array}{c}18.07 \\
\mathrm{~Np}\end{array}$ & $\begin{array}{l}19.19 \\
\mathrm{~Np}\end{array}$ & $\begin{array}{l}\text { CIS } \\
\text { SPu }\end{array}$ & $\begin{array}{l}\text { CL } \\
\text { SP }\end{array}$ \\
\hline 2 & $\begin{array}{l}0.75-6.00 \\
6.00-35.00\end{array}$ & $\begin{array}{c}40.12 \\
\mathrm{~Np}\end{array}$ & $\begin{array}{l}18.82 \\
\mathrm{~Np}\end{array}$ & $\begin{array}{c}21.30 \\
\mathrm{~Np}\end{array}$ & $\begin{array}{l}\mathrm{CIS} \\
\mathrm{SPu}\end{array}$ & $\begin{array}{l}\text { CL } \\
\text { SP }\end{array}$ \\
\hline 3 & $\begin{array}{l}0.00-6.00 \\
6.00-35.00\end{array}$ & $\begin{array}{l}32.33 \\
\mathrm{~Np}\end{array}$ & $\begin{array}{l}16.67 \\
\mathrm{~Np}\end{array}$ & $\begin{array}{l}15.66 \\
\mathrm{~Np}\end{array}$ & $\begin{array}{l}\text { CLS } \\
\text { SPu }\end{array}$ & $\begin{array}{l}\text { CL } \\
\text { SP }\end{array}$ \\
\hline 4 & $\begin{array}{l}0.00-1.50 \\
1.50-3.00 \\
3.00-35.00\end{array}$ & $\begin{array}{c}\mathrm{Np} \\
36.28 \\
\mathrm{~Np}\end{array}$ & $\begin{array}{c}\mathrm{Np} \\
26.25 \\
\mathrm{~Np}\end{array}$ & $\begin{array}{c}\mathrm{Np} \\
20.03 \\
\mathrm{~Np}\end{array}$ & $\begin{array}{l}\mathrm{SPu} \\
\mathrm{CIS} \\
\mathrm{SPu}\end{array}$ & $\begin{array}{l}\text { SP } \\
\text { CL } \\
\text { SP }\end{array}$ \\
\hline 5 & $\begin{array}{l}0.00-4.50 \\
4.50-35.00 \\
\end{array}$ & $\begin{array}{c}39.78 \\
\mathrm{~Np}\end{array}$ & $\begin{array}{c}18.45 \\
\mathrm{~Np}\end{array}$ & $\begin{array}{c}21.33 \\
\mathrm{~Np}\end{array}$ & $\begin{array}{l}\mathrm{CIS} \\
\mathrm{SPu}\end{array}$ & $\begin{array}{l}\text { CL } \\
\text { SP }\end{array}$ \\
\hline
\end{tabular}

\section{Shear Strength and Bearing Capacity}

The shear strength parameters were used to calculate the bearing capacity of the soil at foundation depths below the existing ground level. Furthermore, the unit weights of the soils were also determined. The dimensionless bearing capacity factors were used in the bearing capacity analysis for the foundation.

\section{-Shallow Foundation}

The shear strength parameters $c_{u}$ and $\phi_{u}$ of the cohesive soil samples were obtained from unconsolidated undrained triaxial tests, while shear strength parameter $\square_{\mathrm{d}}$ of the granular soils were evaluated from average SPT-number of the respective stratum. The dimensionless bearing capacity factors after Vesic has been adopted in computing the bearing capacity for shallow foundation:

$\mathrm{q}_{\mathrm{u}}=\mathrm{cN}_{\mathrm{c}} \mathrm{S}_{\mathrm{c}}+\gamma \mathrm{D}\left(\mathrm{N}_{\mathrm{q}}-1\right) \mathrm{S}_{\mathrm{q}}+0.5 \gamma \mathrm{BN}_{\gamma} \mathrm{S}_{\gamma}$

Where $\quad \mathrm{q}_{\mathrm{u}}=$ ultimate bearing capacity

$\mathrm{C}=$ undrained cohesion

$\mathrm{q}=$ effective overburden

$\gamma=$ effective unit weight

$\mathrm{N}_{\mathrm{c},} \mathrm{N}_{\mathrm{q}}, \mathrm{N}_{\mathrm{y}}$ = Bearing capacity factors

$\mathrm{S}_{\mathrm{c}}, \mathrm{S}_{\mathrm{q}}, \mathrm{S}_{\mathrm{y}}=$ Shape factors

The net allowable, $\mathrm{q}_{\mathrm{n}(\mathrm{a})}$, bearing capacity of the soil has been evaluated with a factor of safety (F.S) of 3.0.

Typical calculation of net allowable bearing capacity for $\mathrm{BH} 1$ at $\mathrm{D}_{\mathrm{f}}$ of $1.0 \mathrm{~m}$ for square footing $(\mathrm{B} / \mathrm{L}=1)$ is as follows: $\mathrm{q}_{\mathrm{u}}=1.3 \mathrm{cN}_{\mathrm{c}}+\gamma^{\prime} \mathrm{D}\left(\mathrm{N}_{\mathrm{q}}-1\right)+0.4 \gamma^{\prime} \mathrm{BN}_{\gamma}$

$$
\begin{array}{ll}
\mathrm{c} & =52 \mathrm{kN} / \mathrm{m}^{2} \\
\phi & =5^{\circ} \\
\mathrm{N}_{\mathrm{c}} & =6.49 \\
\mathrm{~N}_{\mathrm{q}} & =1.57 \\
\mathrm{~N}_{\gamma} & =0.45 \\
\gamma^{\prime} & =21.70-9.81=11.89 \mathrm{kN} / \mathrm{m}^{3}
\end{array}
$$

$$
\begin{aligned}
& q_{n(a)}=\frac{q_{n(u)}}{F S}=\frac{[1.3 \times 52 \times 6.49+11.89 \times 1.0 \times(1.57-1)+0.4 \times 11.89 \times 1 \times 0.45]}{3} \\
& \quad=151.67 \mathrm{kN} / \mathrm{m}^{2}
\end{aligned}
$$

Similar calculations for BH1 at depths $2.0 \mathrm{~m}, 3.0 \mathrm{~m}$ and $\mathrm{BH} 2$ to $\mathrm{BH} 5$ at their respective depths were obtained. The submerged unit weight introduced in the analysis is to account for the effect of water on the surcharge component of bearing capacity.

The calculated bearing capacities could be used in determining the shallow foundation type for the structure. An average bearing capacity of $135 \mathrm{kN} / \mathrm{m}^{2}$ is recommended.

\section{Axial Pile Capacity Determination}

\section{-PILE FOUNDATION}

The type of piles that may be adopted for this project are those that are driven (displacement piles) e.g. pre-cast concrete and steel cased piles. This is so as to enable the monitoring of the piling blow counts and remedy any negative skin friction. However, the versatility and cost effectiveness of a particular type of pile will be the governing factor. 
The safe working load of piles are dependent on factors such as pile diameter, founding depth and method of installation which is usually best determined by a specialist-piling contractor from a pile load test.

Allowable pile capacities for axial loading for 406mm (16") tubular driven steel pile have been estimated for the project. Soil profile and geotechnical data obtained from the site were used for the analysis. The following relationships were used for the calculations:

(i) $\mathrm{Q}_{\mathrm{u}}=\mathrm{Q}_{\mathrm{b}}+\mathrm{Q}_{\mathrm{s}}$

(ii) $\quad \mathrm{Q}_{\mathrm{u}}=9 \mathrm{C}_{\mathrm{u}} \mathrm{A}_{\mathrm{b}}+\alpha \mathrm{C}_{\mathrm{u}} \mathrm{A}_{\mathrm{s}}$

(iii) $\mathrm{Q}_{\mathrm{u}}=\mathrm{P}^{\prime}{ }_{\mathrm{o}} \mathrm{N}_{\mathrm{q}} \mathrm{A}_{\mathrm{b}}+\mathrm{k}_{\mathrm{s}} \mathrm{P}_{\mathrm{o}}, \tan \delta \mathrm{A}_{\mathrm{s}} \quad$ for Sand

Where, $\mathrm{Q}_{\mathrm{u}}=$ ultimate bearing capacity of pile $(\mathrm{kN})$

$\mathrm{Q}_{\mathrm{b}}=$ total end bearing $(\mathrm{kN})$

$\mathrm{Q}_{\mathrm{s}}=$ Skin fiction resistance $(\mathrm{kN})$

$\mathrm{C}_{\mathrm{u}}=$ Undrained shear strength of the soil $\left(\mathrm{kN} / \mathrm{m}^{2}\right)$

$\mathrm{A}_{\mathrm{s}}=$ Surface area of pile shaft $\left(\mathrm{m}^{2}\right)=\pi B D$

$\mathrm{A}_{\mathrm{b}}=$ Base area of pile shaft $\left(\mathrm{m}^{2}\right)=\pi \frac{B^{2}}{4}$

$\mathrm{P}^{\prime}{ }_{\mathrm{o}}=$ effective overburden pressure $=\frac{\gamma-\gamma_{w}}{2} D$

$\mathrm{B}=$ Diameter of pile

$\mathrm{D}=$ Depth of penetration

$\alpha=$ Adhesion factor $=0.60$

$\delta=$ Friction angle between the soil and pile wall $=0.60 \phi$

$\mathrm{k}_{\mathrm{s}}=$ Coefficient of horizontal soil stress $=1.5 \mathrm{k}_{\mathrm{o}}$

$\mathrm{k}_{\mathrm{o}} \quad=$ Coefficient of earth pressure at rest $=1-\operatorname{Sin} \phi$

The calculated ultimate pile capacities for BH1 to BH5 are shown in Table 3 below. Allowable axial pile capacity has been obtaining by applying safety factor of 2.5 for driven piles. Plot of depth of penetration versus allowable pile capacities for $406 \mathrm{~mm}$ (16") tubular driven steel piles is shown in figure 7.

It is well established that pile foundation design is not complete without pile load tests [8]; it is therefore recommended that a pi load test be conducted at the site to ensure the design adopted can be safely carried. 


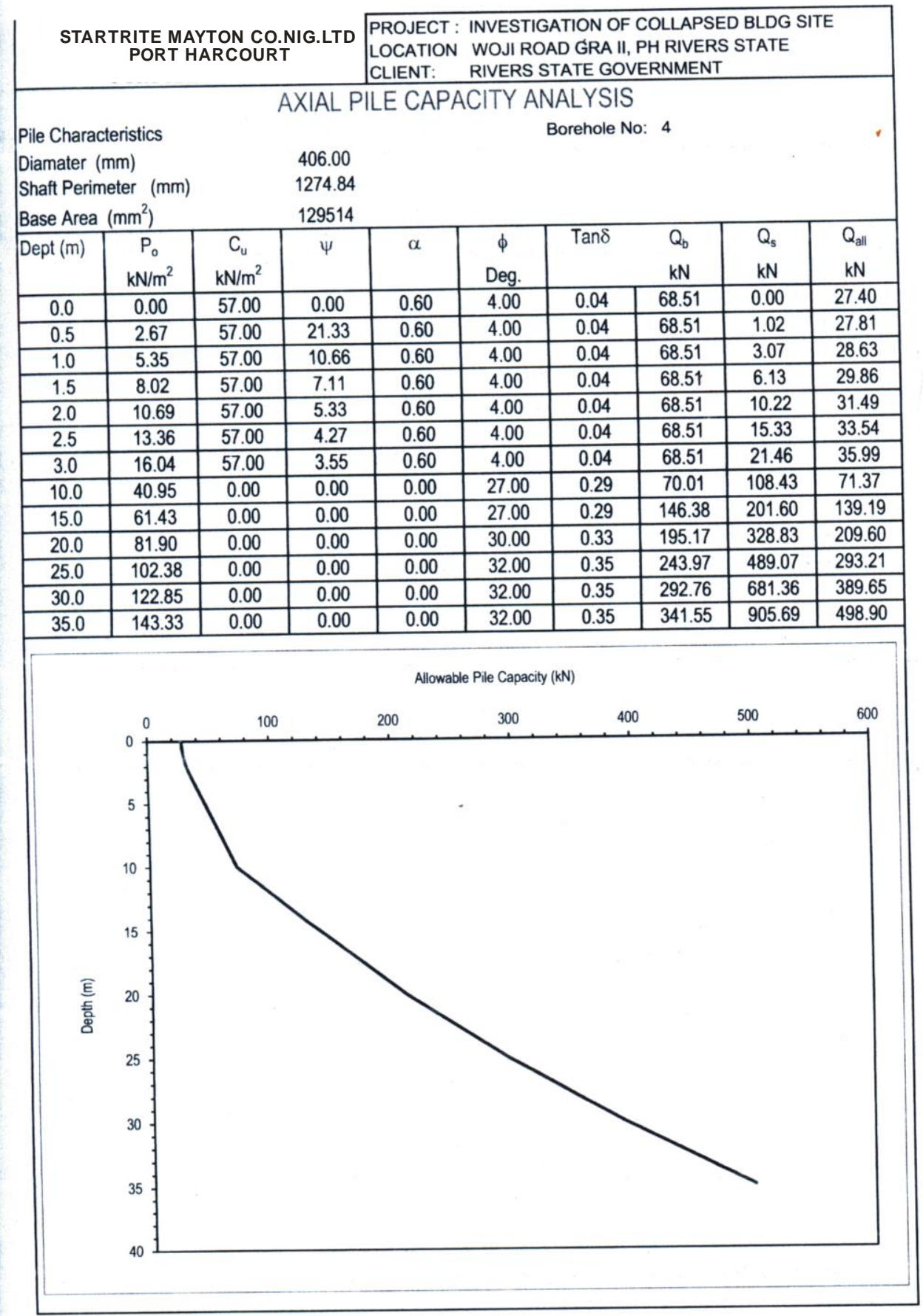

\section{Fig.7: Plot of Borehole Depth Versus Allowable Pile Capacity for 406mm (16") Diameter Driven Casing for Bh4}

\section{SETTLEMENT ANALYSIS}

Total consolidation settlement $\left(\rho_{c}\right)$ has been computed for foundation breadth (B) between 1.00-2.50metres, subjected to a net allowable bearing capacity of $135 \mathrm{kN} / \mathrm{m}^{2}$. Based on the soil lithology, the thickness of the consolidating layer for a square foundation is taken as the depth to the point where the induced vertical stress $(\Delta \sigma)$ is equal to $0.55 \mathrm{q}_{\mathrm{n}}$ [9]. The induced vertical stress $(\Delta \sigma)$ at the centre of the consolidating layer has been used in computing $\rho_{\mathrm{c}}$. The consolidation settlement has been computed from the expression. 


$$
\begin{aligned}
\mathrm{p}_{\mathrm{c}} & =\mu_{\mathrm{g}} \mathrm{P}_{\mathrm{oed}} \\
& =\mathrm{m}_{\mathrm{v}} \sigma_{\mathrm{z}} \mathrm{H} \\
& =\mathrm{m}_{\mathrm{v}} \times 0.55 \mathrm{q}_{\mathrm{n}} \times 1.5 \mathrm{~B}
\end{aligned}
$$

where $\mu_{\mathrm{g}}=$ coefficient which depends on the type of clay

$\mathrm{P}_{\mathrm{oed}}=$ settlement as calculated from oedometer tests

$\mathrm{m}_{\mathrm{v}}=$ coefficient of volume compressibility

$\mathrm{q}_{\mathrm{n}}=$ net foundation pressure

$\mathrm{B}=$ Breadth of foundation.

An $\mathrm{m}_{\mathrm{v}}$ value of $0.12 \mathrm{~m}^{2} / \mathrm{MN}$, which corresponds to the adopted net allowable bearing capacity for the site, has been used in the settlement analysis. The values of total consolidation settlement are presented in Table 2.

Table 2: Settlement Values of Soil.

\begin{tabular}{|r|r|}
\hline Foundation breadth, B $(\mathrm{m})$ & Settlement, $\rho_{\mathrm{c}}(\mathrm{mm})$ \\
\hline 1.0 & 13.37 \\
1.5 & 20.05 \\
2.0 & 26.73 \\
2.5 & 33.41 \\
\hline
\end{tabular}

From Table 2, the computed settlement values for a square foundation breadth of $1.00-2.50 \mathrm{~m}$ is less than the allowable maximum settlements of $65 \mathrm{~mm}$ suggested by Skempton and MacDonald for isolated foundations and 65 $100 \mathrm{~mm}$ for rafts on clay [9]. Hence the soil can sustain a bearing pressure not greater than $135 \mathrm{kN} / \mathrm{m}^{2}$.

\section{CONCLUSIONS AND RECOMMENDATIONS}

The investigation was carried out with the knowledge that a building was constructed at the site and the soils especially at the collapsed area are now overconsolidated (preconsolidated). The implication is that with the vertical effective overburden stresses being once higher at the site, the surcharge loading of the structure has increased the soil cohesion.

The objective of the subsoil investigation was to determine the subsoil conditions prevalent at the location and thereby ascertain the possible causes of the building collapse.

\section{-Soil Classification and Stratigraphy}

The information from deep soil borings and laboratory tests were used in determining the soil stratigraphy of the project site.

The different boreholes drilled have a near consistent uniform soil strata, which exist in two major layers. The soil profile generally consists of a $6 \mathrm{~m}$ thick greyish brown to brown silty clay of intermediate plasticity which is underlain by medium grained, medium dense sand up to the investigated depth of $35 \mathrm{~m}$.

\section{-Safe Bearing Capacity}

I. A bearing capacity value of $135 \mathrm{kN} / \mathrm{m}^{2}$ adopted for shallow foundation is limited to the overburden soft silty clay which extended to a depth of $3.0 \mathrm{~m}$ within which the foundation may be situated.

II. Where the foundation footings are too close to each other, the option of a raft foundation may be considered.

III. Where the calculated safe bearing pressures are not adequate for the installation of a shallow foundation, deep foundation in form of piles are strongly recommended for the structure.

IV. In this country, small diameter piles (up to $450 \mathrm{~mm} / 18$ ") are driven piles while large diameter $(600 \mathrm{~mm} / 24 ")$ and above are usually bored piles[8] .

V. Axial load carrying capacity for $356 \mathrm{~mm}$ (14") and 406 (16") diameter tubular driven steel cased piles were calculated and plots of depth of penetration versus allowable pile capacities for each of the 5 boreholes are presented. It is strongly recommended that all the piles be terminated at the medium dense sand layer at a depth not less than $30 \mathrm{~m}$.

VI. The pile foundation design should be validated with a pile load test to provide qualitative confirmation of the design load adopted and pile settlement.

VII. It was noted that inadequate depth of pile embedment and the absence of a pile load test to determine the safe load capacity of the piles must have been major causes of the sub soil and structural foundation failure.

VIII. Lastly, it is strongly recommended that the design and construction of the foundation of a future superstructure at the site should be carried out in accordance with good engineering practice as embodied in recognized codes of practice such as the British Standard Institution's BS 6031: 1981, Code of Practice for Earthworks and BS 8004: 1986, Code of Practice for Foundations.

\section{ACKNOWLEDGMENT}

The authors express their gratitude to the Judicial Commission of enquiry set up by the Rivers State government for the invitation to carry out this independent study. 


\section{REFERENCES}

[1] P.O. Youdeowei, Report on sub-soil investigations for foundation of blocks of residential buildings, G.R.A. phase 3, Port Harcourt, unpublished. Submitted to Bimkol Engineering (Nig.) Ltd. Port Harcourt, 1995.

[2] P. O. Youdeowei and H. O. Nwankwoala, Suitability of soils as bearing media at a freshwater swamp terrain in the Niger Delta. Journal of Geology and Mining Research, Vol. 5(3), 58-64, 2013.

[3] R.A .Reyment, Aspects of geology of Nigeria. University of Ibadan Press, Nigeria, p.133, 1965.

[4] K.C. Short and A.J. Stauble, Outline of the geology of the Niger Delta. Bull. Am. Ass. Petrol Geol. 54:761 - 779, 1967.

[5] B.S. 1377, Methods of test for soils for civil engineering Purpose, British Standards Institution (BS1), London, 1975.

[6] ASTM, Annual book of America society for testing and materials standards, 1289, Philadelphia, 1979.

[7] R.B. Peck, W.E. Hanson, and T.H. Thornburn, Foundation engineering, $2^{\text {nd }}$ Ed. John Wiley, New York, p. 514, 1974.

[8] V.O. Oyenuga, Design and construction of foundations (A practical approach). Asros Ltd, Lagos, p. 214, 2004.

[9] M.J. Tomlinson, Foundation design and construction. Pitman Advanced Publishing Program, London, $6^{\text {th }}$ Edition, p.536, 1995 . 